\title{
Impact of an ESP Course on English Language Proficiency of Undergraduate Engineering Students: A Case Study at Dhofar University
}

\author{
Julius Irudayasamy ${ }^{1}$, Nizar Mohammed Souidi $^{2} \&$ Carmel Hankins ${ }^{3}$ \\ ${ }^{1}$ Department of English Language and Literature, Dhofar University, Salalah, Sultanate of Oman \\ ${ }^{2}$ Department of English Language and Literature, University of Sousse, Tunisia. \\ Department of English Language and Literature, Dhofar University, Salalah, Sultanate of Oman \\ ${ }^{3}$ Foundation Program, English Language Unit, Dhofar University, Salalah, Sultanate of Oman \\ Correspondence: Julius Irudayasamy, Department of English Language and Literature, Dhofar University, Salalah, \\ PO Box: 2509, PC-211, Sultanate of Oman.
}

Received: February 25, 2020

Accepted: March 25, 2020

Online Published: March 27, 2020

doi:10.5430/ijhe.v9n2p309

URL: https://doi.org/10.5430/ijhe.v9n2p309

\begin{abstract}
Over the last several decades, graduate students from engineering courses have faced a challenge of regular rejections in the work market despite their outstanding academic qualifications. In response to this challenge, many universities across the globe have introduced in their curricula the English for Specific Purposes (ESP) courses tailored to the need of engineering students. The present study evaluated the effectiveness of the ESP course for engineering students introduced at Dhofar University in Oman. The study participants were first- and second-year undergraduates from the Faculty of Engineering. The participants responded to a 26-item survey that addressed the course content and the changes in the students' English language proficiency. The results demonstrated that taking the ESP course had a positive impact on the course content, participants' vocabulary and grammar, as well as on their specific English language skills. The limitations of the study include a relatively small sample of participants and the self-reporting bias inherent in the use of a self-report methodology. Therefore, further research using more objective measures to evaluate the effectiveness and impact of ESP courses on English proficiency of engineering students would be needed.
\end{abstract}

Keywords: English for specific purposes, Engineering English, communication skill, vocabulary and grammar, English as a second language

\section{Introduction}

In the last several decades, there has been a shift from general to specialized paradigms in English language teaching (Terauchi, H., Noguchi, J., \& Tajino, A., 2019). English language teaching was perceived as a social practice (Ellis, 2012), and learners were made to acquire the basic concepts of the language for social reasons, and therefore, no particular course focused on the development of English communication skills was available (Harmer, 1991). Accordingly, most universities and colleges in regions where English was not the primary language of communication, were less concerned about the English language competency of their learners. Hence General English language courses in these areas were not specific to any course content.

In today's globalized world where English is the most widely used language of communication in institutional and government offices and instruction in all higher academic institutions (Essen, 2004), a high level of English proficiency is of paramount importance for students' professional development. English has become the predominant language for studies in engineering, international commerce, tourism, international relations, trade, education, science, and technological research (Essen, 2004). In the corporate world, employers and managers need people who are not only experts in their respective areas but who can also communicate with different groups of people, therefore, requiring a high level of English competency (Mckay, 2003).

The challenges of the present-day globalized world have led to significant changes in the academic curricula of the world's universities. In most higher education institutions, English for Specific Purposes (ESP) courses have been introduced. ESP is primarily defined as a sphere of English teaching focused on students' acquisition of competence in those English language skills that are most appropriate for the students' professional lives . (Li, Y. F., Wang, X. Y., 
\& Feng, H. L., 2018; Garmash, S., 2017). In the field of engineering, the ESP courses prepare engineering students to be able to read specialized texts, comprehend lecturers and tutorials in English, and freely express themselves in discussions on engineering topics.

Despite the comprehensive introduction of ESP courses for engineering students at many universities across the globe, engineering students show a general lack of concern regarding the significance English has for their future careers, and there are several reasons behind this lack of motivation and interest. Some students fail to realize that proficiency in English is a competitive advantage in today's globalized work market. Another reason is that many ESP courses are not sufficiently practice-oriented (Harmer, 1991). Therefore, students are unable to effectively create links between the knowledge acquired in class and real-life experiences, events and requirements. Finally, as engineering courses emphasize on quantitative and mathematical knowledge such as competency in calculations, understanding figures and interpreting real life observation, ESP courses are orientated towards introspective language usage, developing personality and self-expression. These attributes are not seen by the students as helpful to the traditional engineering career (Tabrizi \& Renani, 2016). These issues have resulted in engineering students' detrimental lack of primary English language skills, such as speaking, vocabulary and grammar usage (Hutchinson \& Waters, 1986). Despite outstanding academic qualifications, engineering graduates are unable to satisfactorily convince the interviewers during job interviews or in job applications (Shrestha, R. N., Awasthi, J. R., \& Pahari, B. R., 2018) Consequently, there is an urgent need to develop engineering students' English language proficiency through the most effective and efficient strategies for teaching in particular, through the newly introduced course of English for specific purposes for engineering students (Widdowson, 2011).

\subsection{Importance of ESP for Engineering Students in Oman}

Owing to the dominant status of English in science and technology (Sharma \& Mishra, 2009), proficiency in the English for engineers and scientists is essential for Oman's national development. Proficiency in English language is also vital for research and academic institutions in Oman since a considerable part of scientific or technological journals across the globe publish papers written in English (Mitra, 2006). In the English for the International Language of Science (EILS) framework, proficiency in English enables people to enjoy better treatments, get competitive advantages in the labor market, and acquire a higher status internationally (Tharu, 2006). In this context, enhancing the English proficiency of student bodies in Omani universities will help graduate students occupy international leadership positions across the fields of technology, engineering, and science (Basta, 2011). In the modern era of globalization, English language assessment has become an essential part of the job recruitment process (Zughoul \& Hussein, 2005) which has led to the understanding that ESP programs for engineering students are an important part of preparing students to be competent in real-life job search and professional development on the global arena.

Similar to other universities in Oman as well as abroad, Dhofar University traditionally offered only General English and Academic English teaching programs. However, the current curriculum of Dhofar University also includes ESP courses, as they have been reported to offer significant benefits for students in tertiary institutions (Tabrizi \& Renani, 2016). There is also evidence showing that students who take the ESP course for engineering can link language learning with their professional reality (Mckay, 2003).

According to Omani National Centre for Statistics and Information (NCSI, 2017), Oman currently has 69 higher education institutions, including 31 public and 29 private institutions including Dhofar University. At present, the curricula of these higher education institutions include a communicative English course for the first- and second-year students. In many of these institutions, these programs have now been rebranded as English for Specific Purpose (ESP) courses, and in these courses, undergraduate students are introduced to ELT (English Learning and Teaching) (Lynch, 1996). The length of these courses are generally two to three semesters and comprise of both theoretical and practical sessions.

\subsection{The Present Study: Research Questions}

At Dhofar University, ESP for Engineering is offered and is designed as part of the regular engineering syllabus. The overall objectives of ESP for Engineers are as follows:

i) To recognize and recall the meaning of specific engineering vocabulary

ii) To develop grammatical skill by Identifying the targeted grammatical structures

iii) To Infer the meaning of key engineering vocabulary as given in the context 
iv) To apply comprehension skills by locating answers to reading comprehension questions in engineering and science texts

v) To analyze an engineering situation and construct a properly structured descriptive writing

vi) To develop basic research skills by summarizing academic and engineering-related texts

vii) To apply basic research skills through constructing a project related to an engineering or science-related situation

viii) To evaluate oral competency through presentation and discussion on an on-going research project

The present study aims to evaluate the effectiveness of this ESP course for engineering students at Dhofar University. The specific research questions addressed in this study are as follows:

(1) How do engineering students perceive the ESP course?

(2) What impact does the ESP course have on engineering students' specific language skills?

(3) What impact does the ESP course have on engineering students' vocabulary and grammar?

The hypothesis is that the course positively affects engineering students' language competency and proficiency in all key language learning areas.

\section{Literature Review}

Within the modern era of globalization, perfect and outstanding communication skills are the only gateway to professional job success. In this sense, students with exceptional communication skills, writing skills, dynamic personality, and commendable self-expression are considered to be significant assets to any organization. In support of this assertion, Ellis (2012) affirmed that the success of any academic and professional idea and thought, hinged solely on the ability of an individual to effectively communicate this idea. Competition among different companies, organizations, or professions require that all individuals are expected to do more with scarce or limited resources. Accordingly, excellent communication skills have become an explicit requirement in current job scrutiny tests (Morgan \& Regan, 2008). These tests sometimes include full or partial English or communicational knowledge. Any knowledge or skill might not be of great significance until it gets expressed in a proper language. However, many engineering students lack professional communication skills, both in writing and in spoken language (Mudraya, 2006).

Mckay (2003) argued that communication plays a pivotal role in professional career development. Hence, effective communication skills are vital to students' professional success. Many reviews have found that such skills are greatly lacking among engineering students, which negatively impacts their academic success, professional communication, and employability (Kamsah, M. Z., 2004). It has been argued that the ESP courses for engineering students where students learn the English language and communication skills unique to their profession and career prospects are absolute necessity (Hossain, 2013). Cheremissina and Reimer (2001) described English as a 'mediator in shaping future engineers' (p.58). The individual benefits of ESP are further amplified by the requirement for each course to be tailor made by the teacher for their students, as standard textbooks are rarely able to accomplish the specific task of teaching engineering ESP (Cheremissina \& Reimer, 2001).

Several literature surveys on language proficiency and communicative competence have explicitly focused on English proficiency levels among engineering students (Popescu, A. V., 2012; Zughoul \& Hussein, 2005; Ahmad, J., \& Ahmad, J., 2012). Utilizing primarily secondary data, surveys unanimously revealed that along with technical expertise directly associated with career success, engineering students need to acquire English communicative skills. Similarly, language educators and sectorial professionals have emphasized the importance of essential communication skills, including being to understand and articulate issues within the wider society, such as awareness of the social justice, conflict resolution traits, ethics, sustainability awareness, and teamwork skills (Kassim, H., \& Ali, F., 2010; Riemer, M. J., 2007). Tabrizi and Renani (2016) highlighted, the need to improve English communicative skills and competence among engineering graduates and professionals has been at the center of linguistics discussion and research. Engineers work in knowledge-intensive environments necessitates both problem-solving abilities and high-level communicative competencies and skills. Ellis (2012) argued that graduate engineers should be able to combine problem-solving skills with excellent communication skills, engineering knowledge, and technical expertise. Mitra (2006) supported the introduction of ESP for engineering, which will continue to improve the English language proficiency and communication skills among the cohort. 


\section{Methodology}

\subsection{Study Participants}

The study participants were 118 students from the Faculty of Engineering at Dhofar University. The respondents included the first-year $(\mathrm{N}=88 ; 74.5 \%)$ and second-year $(\mathrm{N}=30 ; 24.5 \%)$ undergraduates. The participants' age ranged from 19 to 30 years old (mean=21, with most students $(\mathrm{N}=50 ; 42.3 \%)$ aged 22-25 years old. In terms of gender distribution, the vast majority of the study participants were male $(\mathrm{N}=102 ; 86.4 \%)$. The same gender imbalance is reflected in the engineering course. Rasha (2017), states that there is gender equality in the workplace in terms of payment and promotion; the author further argues why the dwindling numbers of women engineers joining the workforce after graduation. A possible explanation is that within the Omani female student body, many women do not undertake Engineering courses due to perceived practical issues such as on-site work and field work which may sometimes require a long period time travelling away from family. Instead, the female population within Omani universities often prefer Chemical or Computer engineering as these subjects are taught in a lab or classroom setting. All respondents were taking the ESP course for engineering students at Dhofar University. Most students ( $\mathrm{N}=82$; 69.4\%) had taken a similar course before (see Table 1).

\subsection{Questionnaire Construction}

The data was collected using the Likert scale questionnaire technique which allows participants to rank levels of agreement or disagreement towards specific statements (Likert, 1932). In addition, open-ended questions were included towards the end of the survey to collect qualitative data. Prior to the design and development of the questionnaire items, an in-depth review of the literature on how to develop the study items was conducted. Based on the results of this review, a 26 item questionnaire was developed (see Annex 1). The questionnaire had items in the following four major sections (i)the course content (e.g., "The amount of course content is adequate") (Q1-6); (ii) specific skills from the ESP course (e.g., "I can describe technical functions and applications in English") (Q7-15); (iii) grammar and vocabulary (e.g., "I am able to use English technical vocabulary in my major course assessments") (Q16-23); (iv) open-ended questions (e.g., "Why do you think that English for Engineering or General English course is useful?") (Q24-26). The items in categories (i)-(iii) were rated on a 4-point scale ranging from "Strongly Disagree" to "Strongly Agree". Students were free to give more information at the end (Q26) if they wished.

\subsection{Data Collection}

The questionnaire was distributed among 118 students: 88 first-year and 30 second-year students (course codes ENG $102 \mathrm{E}$ and ENG 203E, respectively). All participants responded positively by filling in the questionnaire questions. The completed questionnaires were collected for further data analysis.

\subsection{Response Rate}

The response rate was $100 \%$, as all students voluntarily completed the questionnaire. No compensation was offered to the participants. There were no drop-outs or incomplete responses.

\subsection{Data Analysis}

Quantitative data were analyzed using Excel. The descriptive statistics regarding the study participants' demographic characteristics, language proficiency, and participation in a previous ESP course were counted (see Table 1) and then converted to percentages. The same procedure was applied to the analysis of the participants' responses to questionnaire items in sections (i)-(iii). Qualitative data in section (iv) was analyzed by identifying common threads and themes within the answers (e.g., "Key Engineering vocabulary is exposed through this course").

\section{Results}

First, with regard to the level of English proficiency, most students $(\mathrm{N}=60,50.8 \%)$ had a good level, followed by very good $(\mathrm{N}=32 ; 27.1 \%)$, average $(\mathrm{N}=22 ; 18.7 \%)$, and excellent $(\mathrm{N}=4 ; 3.4 \%)$ (see Table 1$)$. 
Table 1. Demographic characteristics and English proficiency levels of study participants

\begin{tabular}{lllll}
\hline Course code & & ENG 102E & ENG 203 E & Total \\
\hline $\begin{array}{l}\text { Number } \\
\text { participants }\end{array}$ & of & 88 & 30 & 118 \\
Age & & & & \\
& 18-21 years & 8 & 10 & 18 \\
& $22-25$ years & 34 & 16 & 50 \\
& 26-29 years & 36 & 0 & 36 \\
Gender & $\geq 30$ years & 10 & 4 & 14 \\
& male & 78 & 24 & 102 \\
English proficiency & female & 10 & 6 & 16 \\
& Average & 20 & 2 & 22 \\
& Good & 42 & 18 & 60 \\
& Very good & 22 & 10 & 32 \\
Similar course & Excellent & 4 & 0 & 4 \\
before & Yes & 56 & 26 & 82 \\
& & 32 & 4 & 36 \\
\hline
\end{tabular}

These initial quantitative results suggest that the ESP course for engineering students had a positive impact on English proficiency levels of engineering students (cf. Sharma \& Mishra, 2009). Though there should be an awareness of self-reporting bias with regards to English proficiency, the high number of returning students implies a positive reaction to taking part in ESP courses. (Figures 1-3). Analysis of responses shows that participants felt the courses had a positive impact on their proficiency in specific language skills specific to engineering. First, most students agreed with positive statements about the course content (Q1), coverage of topics (Q2, Q5), and duration (Q6). Most students in the two study groups also reported that, after the ESP course, their interest in learning English from this

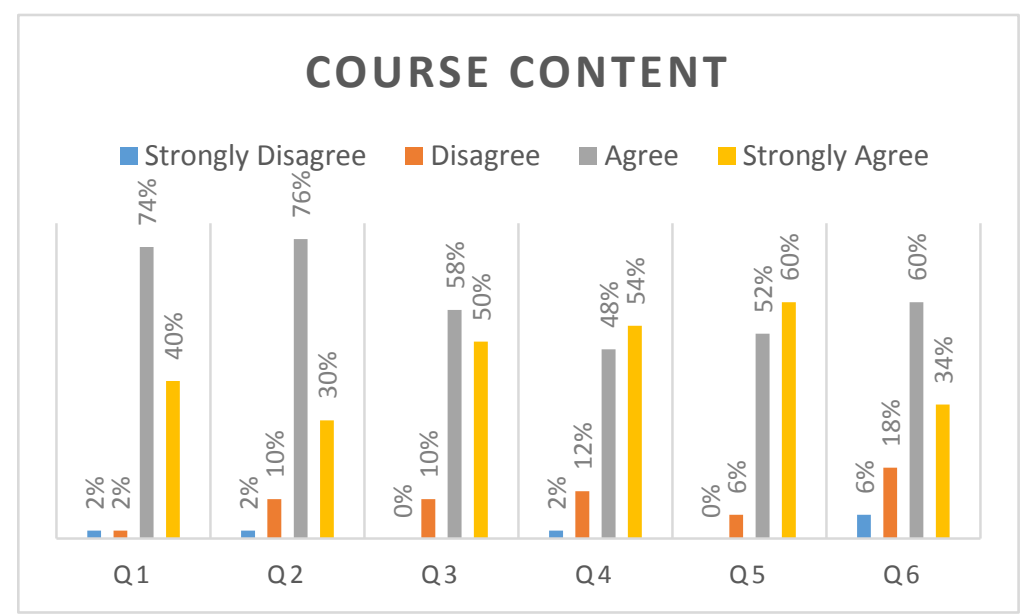

Figure 1. Study participants' assessment of the ESP course content

perspective increased (Q4) (see Figure 1). Second, most students positively evaluated changes in their specific language skills after the ESP course (see Figure 2). This included the students' ability to describe technical functions and applications (Q4), manufacturing techniques and processes (Q7), solve technical problems (Q8) or provide technical explanations (Q5), and so forth (see Annex for further items). Thirdly, most study participants also reported that their vocabulary and grammar skills had also been considerably improved after the ESP course (Figure 3). This included learning and mastering relevant prepositions (Q6), verbs (Q7), and technical vocabulary more generally (Q2; see Annex for other items). 


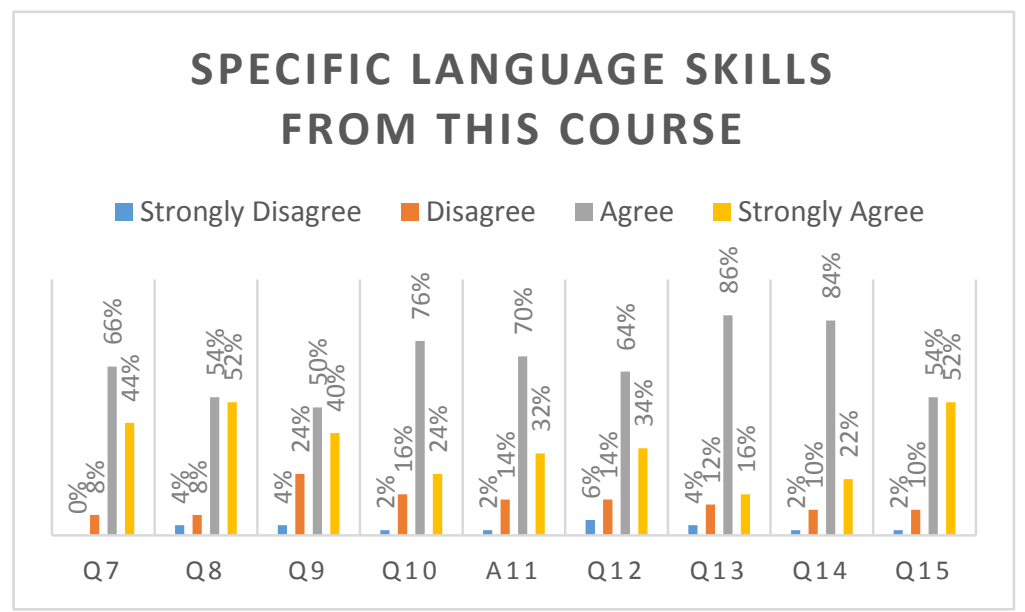

Figure 2. Study participants' assessment of specific language skills they have acquired in the ESP course

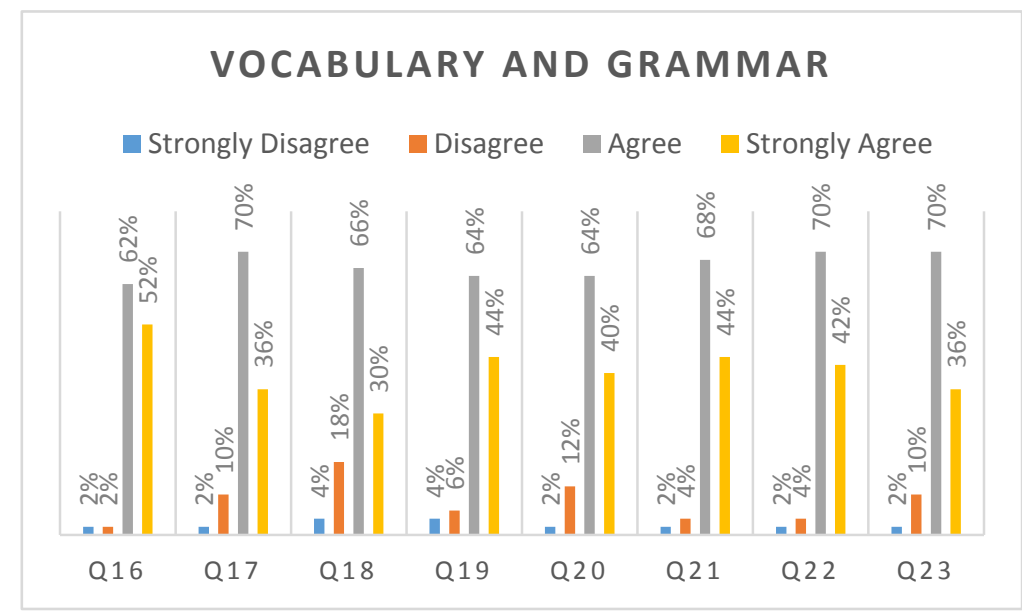

Figure 3. Study participants' assessment of vocabulary and grammar they have acquired in the ESP course

In summary, from the results shown in Figure 1-3, it can be concluded that the introduction of ESP for engineering students has significantly increased the students' motivation to learn English and positively influenced their grammar, vocabulary, and speaking skills.

\section{Discussion and Conclusion}

The present study evaluated the effectiveness of the ESP course for engineering students introduced at Dhofar University in Oman. The study participants were first- and second-year undergraduates from the Faculty of Engineering. The participants responded to a survey that addressed the course content and the changes in the students' English language proficiency. The results demonstrated that taking the ESP course had a positive impact on the participants' vocabulary and grammar, as well as on their English-speaking skills. The respondents also positively evaluated the ESP course in terms of its scope and duration.

The Open-ended question results echo similar ideas. Answers to Q24 (Why do you think that English for Engineering course is useful?) showed that students acknowledged that they tremendously improved their science-oriented understanding through this ESP course. Even specific engineering enhanced their English proficiency. Some students also reported that ESP would improve their chances of obtaining a good career in Engineering. However, answers to Q25 (Do you encourage other students to register for this ESP or General English course? If yes or no, give reasons) 
reflected a critical mindset. Most criticisms reflected the idea that English is a useful tool for communication, and subject-specific knowledge is not necessary. Some answers were more specific, arguing that subject-specific vocabulary retention in the course was poor. Another response reflected that a few students' GPA went down because of this particular ESP course. Presumably, general English courses could have helped these students to get a higher score. Nonetheless, the general gist of results across Q24-26 is positive, and a large number of students recommend ESP courses to other students.

In conclusion, this study shows a generally positive relationship between participation in ESP courses and engineering students' English proficiency levels. Students answered positively when asked if they would recommend the course to others showing a continued interest within the student body towards ESP courses. These results are consistent with those reported in previous studies such as Zughoul and Hussein's (2005) study. Overall, there is a broad scholarly consensus that, due to being very intensive and narrow-focused, ESP programs offer enormous benefits to the engineering profession (Tabrizi \& Renani, 2016). These programs help non-native English students to develop their understanding of engineering using the language that is nowadays most widely used in their respective professional context (Huckin \& Olsen, 1991). Therefore, ESP courses for engineering students are essential, as they prepare students for their professional careers (Mudraya, 2006).

\subsection{Limitations}

The present study has several limitations. First, there was a relatively small sample, and all participants were from the Department of Engineering at Dhofar University. Future studies should have larger participant numbers from a more diverse range of faculties in order to give a clearer image of English language learning and training (Oxford, 2014) Second, most participants in our sample were male students. Future research would benefit from considering more gender-balanced samples. Omani college girls do not prefer Engineering course due to practical issues such as on-site work, field trips, and leaving family away for remote fieldwork. Most of the girl students prefer Chemical or Computer engineering courses as they prefer laboratory or office work. Third, the use of the self-report questionnaire could have led to the self-reporting bias in the data, particularly in the students' self-rating their levels of proficiency in English. Therefore, in future research, it would be necessary to measure the changes in engineering students' levels of competence before and after an ESP course using objective measurement tools.

\subsection{Suggestions}

Results from the study reveal that engineering students are able to improve their specific language skills. Qualitative findings from the survey suggest that students who are not in favor of the ESP course need to take general English courses to anchor their basic language skills before registering ESP course. Strengthening General English proficiency levels will allow participants of the ESP course to easily understand complicated topics both in terms of linguistics and subject matter. One student reported, for example, that he assumes the ESP course's 'Native Speaker's English' in a recording was too difficult to understand, another student reported difficulties in understanding the ESP 'technical reading'. A strengthening of the General English course could help alleviate some of these issues before taking any ESP courses.

One such method of doing this could be to strengthen the commitment and creativity of both ESP and General English teachers and instructors. Teachers should focus on creating a positive attitude towards communication in a 'foreign language' by providing motivation, counselling, soft skills training and communication advice to their students (Mckay, 2003). There is also the need for free and friendly interaction between language teachers and their students, so that the students can openly express their opinions and discuss their difficulties in learning and training, all of which will improve students' English communication skills.

Furthermore, students should also be offered participation in various programs such as debates, group discussions, JAM sessions, and role-plays, among other types of activities. These supplementary programs will strengthen students' confidence and competency levels through daily practice of the language (Harmer, 1991). Students are also encouraged to regularly read available English resources, such as magazines, newspapers and e-resources, which would help cultivate their reading abilities (cf. Vennakkadan \& Irudayasamy 2014, 2017). Reading is well known to have a strong positive impact on students' levels of proficiency in English (Tabrizi \& Renani, 2016). In addition, it is essential to promote technology-aided (computer-assisted) learning, where students can also develop technical-based language skills (Irudayasamy, Hankins, \& March, 2018; Sharma \& Mishra, 2009). This strategy would be effective in engaging English language learners through enhancing their motivation to learn the language, developing their writing, editing, pronunciation, and speaking skills (Fry, Ketteridge, \& Marshall, 2008). Such awareness of students' backgrounds, original literary experience, and prevailing challenges and benefits of the ESP programs would enable teachers to more effectively teach the language in English as a Second Language classroom (Nunan, 1999). 


\section{Acknowledgements}

I would like to express my most profound appreciation to all those who provided me the possibility to complete this research paper. I wish to pace on records my sincere gratitude to my co-author, Dr. Nizar Mohammed Souidi for his valuable contributions and insights to complete this paper successfully. Special gratitude to another co-author, Ms. Carmel Antonette Hankins, for her incredible contributions and stimulating suggestions. She has tremendously coordinated with me to complete this paper effectively. I would like to thank my students from the faculty of Engineering for their patience to complete the questionnaire to formulate the results. Finally, I would like to thank my colleagues for their writing assistance and proofreading the article.

\section{References}

Ahmad, J., \& Ahmad, J. (2012). Theoretical framework \& growing demand of ESP in Saudi Arabia. الآداب و العلوم الإنسانية

Basta, J. (2011). The role of the communicative approach and cooperative learning in higher education. Facta Universitatis (Series: Linguistics and Literature), 9(2), 125-144.

Cheremissina, I. \& Riemer, M. (2001). English for Specific Purposes in engineering education at the Tomsk Polytechnic University.

Deckert, G. (1987). The communicative approach: Helping students adjust. English Teaching Forum, 25(3), 17-20.

Ellis, R. (2012). Communication skills: Stepladders to success for the professional. Bristol: Intellect Books.

Essen, A. V. (2004). The rise and role of English as an international language: Some educational consequences. Humanising Language Teaching, 4, 1-9.

Fry, H., Ketteridge, S., \& Marshall, S. (2008). A handbook for teaching and learning in higher education: Enhancing academic practice. London and New York, NY: Routledge. https://doi.org/10.4324/9780203891414

Garmash, S. (2017). ESP in teaching foreign students of engineering specialities (tasks, problems and solutions) (Doctoral dissertation, НТУ" ХПІ").

Harmer, J. (1991). The practice of English language teaching. London/New York, NY: Longman.

Hossain, Jamal. "ESP needs analysis for engineering students: A learner centered approach." Presidency University 2.2 (2013), 16-26.

Huckin, T. N., \& Olsen, L. A. (1991). Technical writing and professional communication for non-native speakers of English. New York, NY: McGraw-Hill International Editors, pg. 3.

Hutchinson, T. \& Waters, A. (1986). English for specific purposes: A learning-centered approach. New York, NY: Cambridge University Press.

Irudayasamy, J., Hankins, C. A., \& March, M. (2018). Creating a web-based communicative learning environment through interactive blogs: English language acquisition. Arab World English Journal (AWEJ), 4, 260 - 271. https://doi.org/10.24093/awej/call4.20

Kamsah, M. Z. (2004, December). Developing Generic Skills in Classroom Environment: Engineering Student's Perspective. In Conference On Engineering Education (CEE 2004) (pp. 14-15).

Kassim, H., \& Ali, F. (2010). English communicative events and skills needed at the workplace: Feedback from the industry. English for specific purposes, 29(3), 168-182. https://doi.org/10.1016/j.esp.2009.10.002

Li, Y. F., Wang, X. Y., \& Feng, H. L. (2018). The Application of Mind Map in ESP Teaching and Learning. In 4th Annual International Conference on Management, Economics and Social Development (ICMESD 2018). Atlantis Press. https://doi.org/10.2991/icmesd-18.2018.80

Likert, R. (1932). A Technique for the Measurement of Attitudes. Archives of Psychology, 140, 1-55.

Lynch, B. K. (1996). Language program evaluation: Theory and practice. Cambridge: Cambridge University Press.

Mckay, M. A. J. (2003). English for specific purposes. London: Longman.

Mitra, B. K. (2006). Effective technical communication: A guide for scientists and engineers. New Delhi: Oxford University Press, USA.

Morgan, D., \& Regan, N. (2008). Take-off: Technical English for engineering: Course book. Reading, UK: Garnet Publishing. 
Mudraya, O. (2006). Engineering English: A lexical frequency instructional model. English for Specific Purposes, 25(2), 235-256. https://doi.org/10.1016/j.esp.2005.05.002

National Centre for Statistics and Information. (2017). Higher Education Statistics. Retrieved February 25, 2020, from https://www.ncsi.gov.om/Elibrary/Pages/LibraryContentView.aspx

Nunan, D. (1999). Second language teaching \& learning. Boston, MA: Heinle \& Heinle Publishers.

Oxford, R. L. (2011). Teaching and researching language learning strategies. Harlow, UK: Pearson Longman.

Popescu, A. V. (2012). Teaching ESP-1st year students of electronics and telecommunications. Procedia-Social and Behavioral Sciences, 46, 4181-4185. https://doi.org/10.1016/j.sbspro.2012.06.222

Raisi, A.R. (2017). Why woman engineers don't join workforce? Oman Observer. Retrieved from https://www.omanobserver.om/woman-engineers-dont-join-workforce/

Riemer, M. J. (2007). Communication skills for the 21st century engineer. Global J. of Engng. Educ, 11(1), 89-100.

Sharma, S., \& Mishra, B. (2009). Communication skills for engineers and scientists. New Delhi: PHI Learning Private Limited.

Shrestha, R. N., Awasthi, J. R., \& Pahari, B. R. (2018). Impact of English Language Proficiency on the Job Grabbing Process of Engineers in Nepal and the Other Countries: A Bird's Eye View. Journal of the Institute of Engineering, 14(1), 223-234. https://doi.org/10.3126/jie.v14i1.20088

Tabrizi, A. R. N. \& Renani, F. M. (2016). ESP Needs analysis of undergraduate mechanical engineering students: A case in Iran. International Journal of Humanities and Cultural Studies (IJHCS), 3(2), 1696-1707.

Tharu, J. (2006). A second look at English as a window on the world that has changed. Communication Curriculum in Higher Communication: Challenges \& Opportunities.

Terauchi, H., Noguchi, J., \& Tajino, A. (Eds.). (2019). Towards a New Paradigm for English Language Teaching: English for Specific Purposes in Asia and Beyond. Routledge. https://doi.org/10.4324/9780429423963

Vennakkadan, A. L., \& Irudayasamy, J. (2014). Tightening the grip over an elusive system: Innovative practices. English Language Teaching; 7(8), 116-123. https://doi.org/10.5539/elt.v7n8p116

Vennakkadan, A. L., \& Irudayasamy, J. (2017). Investigating the Omani EFL learners' English reading habit and its impacts on other macro-skills. Scholars Journal of Arts, Humanities and Social Sciences, 5(11B):1648-1654. https://doi.org/10.21276/sjahss.2017.5.11.15

Widdowson, H. G. (2011). Teaching language as communication. Oxford and New York. NY: Oxford University Press.

Zughoul, M. R., \& Hussein, R. F. (2005). English for higher education in the Arab world: A case study of needs $\begin{array}{llll}\text { analysis at } \quad \text { Yarmouk University. The } & \text { ESP }\end{array}$ https://doi.org/10.1016/0272-2380(85)90016-2 


\section{Annex 1}

\section{Questionnaire}

Do not write your name or any identification number.

$>$ This questionnaire is part of an academic research. Your cooperation will aid the research.

$>$ The researcher promises to maintain strict confidentiality of your information.

$>$ Please circle / put a tick on the correct options and provide the required information.
a) Course code: 102E
$203 \mathrm{E}$

b) Your age: $18-21$

$22-25$

26-29

$30+$

c) Your gender: Male Female

d) Level of proficiency in English: Average Good Very good Excellent

e) Have you done a similar technical course before joining DU? Yes N No

\section{i) Course content}

\begin{tabular}{|c|c|c|c|c|c|}
\hline$\#$ & Questions & $\begin{array}{l}\text { Strongly } \\
\text { Disagree }\end{array}$ & Disagree & Agree & $\begin{array}{l}\text { Strongly } \\
\text { Agree }\end{array}$ \\
\hline 1 & The course objectives are easy to understand. & & & & \\
\hline 2 & The amount of course content is adequate. & & & & \\
\hline 3 & $\begin{array}{l}\text { I am able to achieve the goals mentioned in the } \\
\text { study plan. }\end{array}$ & & & & \\
\hline 4 & $\begin{array}{l}\text { My interest in this ESP course (English for } \\
\text { Engineering) has increased. }\end{array}$ & & & & \\
\hline 5 & $\begin{array}{l}\text { Number of units covered in this course is } \\
\text { enough. }\end{array}$ & & & & \\
\hline 6 & $\begin{array}{l}\text { The time allotted for the course content is } \\
\text { adequate. }\end{array}$ & & & & \\
\hline
\end{tabular}




\section{ii) Specific language skills}

\begin{tabular}{|c|c|c|c|c|c|}
\hline$\#$ & Questions & $\begin{array}{l}\text { Strongly } \\
\text { Disagree }\end{array}$ & Disagree & Agree & $\begin{array}{l}\text { Strongly } \\
\text { Agree }\end{array}$ \\
\hline 7 & $\begin{array}{l}\text { I have acquired adequate language skills after } \\
\text { taking this course. }\end{array}$ & & & & \\
\hline 8 & $\begin{array}{l}\text { I find reading English texts from the field of } \\
\text { specialization to be useful. }\end{array}$ & & & & \\
\hline 9 & $\begin{array}{l}\text { I have read engineering-related texts in English } \\
\text { for the first time. }\end{array}$ & & & & \\
\hline 10 & $\begin{array}{l}\text { I can describe technical functions and } \\
\text { applications in English. }\end{array}$ & & & & \\
\hline 11 & $\begin{array}{l}\text { I am able to describe technical components from } \\
\text { the units in English. }\end{array}$ & & & & \\
\hline 12 & $\begin{array}{l}\text { I am able to explain manufacturing techniques } \\
\text { and processes in English. }\end{array}$ & & & & \\
\hline 13 & $\begin{array}{l}\text { I can describe different types of technical } \\
\text { problems in English. }\end{array}$ & & & & \\
\hline 14 & $\begin{array}{l}\text { I am able to suggest ideas and solutions in } \\
\text { English. }\end{array}$ & & & & \\
\hline 15 & $\begin{array}{l}\text { I believe that my ability to relate the content and } \\
\text { the language skills developed in this course } \\
\text { would be beneficial for my major and } \\
\text { professional career. }\end{array}$ & & & & \\
\hline
\end{tabular}




\section{iii) Vocabulary and Grammar}

\begin{tabular}{|c|c|c|c|c|c|}
\hline \# & Questions & $\begin{array}{l}\text { Strongly } \\
\text { Disagree }\end{array}$ & Disagree & Agree & $\begin{array}{l}\text { Strongly } \\
\text { Agree }\end{array}$ \\
\hline 16 & $\begin{array}{l}\text { I have learnt many technical vocabulary items in } \\
\text { this course. }\end{array}$ & & & & \\
\hline 17 & $\begin{array}{l}\text { I am able to use English technical vocabulary in } \\
\text { my major course assessments. }\end{array}$ & & & & \\
\hline 18 & $\begin{array}{l}\text { I have learnt words related to safety and } \\
\text { precautions. }\end{array}$ & & & & \\
\hline 19 & $\begin{array}{l}\text { These English words are useful for my major } \\
\text { courses while speaking with my Instructors }\end{array}$ & & & & \\
\hline 20 & I have learnt English prepositions in this course. & & & & \\
\hline 21 & $\begin{array}{l}\text { I am able to use the verbs describing repairs and } \\
\text { maintenance in short texts }\end{array}$ & & & & \\
\hline 22 & I find grammar items in this course to be useful. & & & & \\
\hline 23 & $\begin{array}{l}\text { I am confident and able to use the sub-skills in } \\
\text { the future }\end{array}$ & & & & \\
\hline
\end{tabular}

\section{iv) Open-ended questions}

24. Why do you think that English for Engineering or General English course is useful?

25. Do you encourage other students to register for this ESP course or General English? Please give reasons.

26. Any other comments 